\title{
Abnormal uterine bleeding in women of peri-menopausal age: a retrospective study
}

\author{
Rambabu Chennuru, Ramkumar Potnuru*
}

\begin{abstract}
Department of Obstetrics and Gynecology, NRI Institute of Medical sciences, Sangivalasa, Visakhapatnam, Andhra Pradesh, India
\end{abstract}

Received: 02 April 2019

Accepted: 06 May 2019

\section{*Correspondence:}

Dr. Ramkumar Potnuru,

E-mail: drram_potnuru@yahoo.co.in

Copyright: () the author(s), publisher and licensee Medip Academy. This is an open-access article distributed under the terms of the Creative Commons Attribution Non-Commercial License, which permits unrestricted non-commercial use, distribution, and reproduction in any medium, provided the original work is properly cited.

\begin{abstract}
Background: Abnormal uterine bleeding (AUB) is a phenomenon which refers to menstrual bleeding of abnormal frequency, duration or quantity. It is a common gynaecological complaint caused by wide variety of organic or nonorganic causes. The objective of the study was to determine the incidence of abnormal uterine bleeding with respect to aetiopathology, demographic variables, treatment options and other medical disorders.

Methods: A retrospective study of randomly selected 200 cases of abnormal uterine bleeding between 40-55 years of age during January 2018 to January 2019, in the Dept. of Obstetrics and Gynaecology, in a tertiary care hospital. Demographic details of each patient were recorded and analysed. Patients were evaluated with menstrual history, physical examination, laboratory tests and histological examinations. Patients were followed up from 3 to 8 months.

Results: Most common age group presenting with AUB was 40-45 years (65.55\%) and mostly (68.33\%) belonged to low socioeconomic status. Most of the women were multiparous and menorrhagia was most common presentation. In $60 \%$ cases, cause was non-organic (dysfunctional uterine bleeding) and among organic causes fibroid (21\%) uterus was most common. Maximum number of patients (75\%) was treated surgically and $20 \%$ got medical treatment.

Conclusions: Abnormal uterine bleeding (AUB) is a common gynaecological manifestation allied with considerable morbidity and significantly affects the patient's family, personal and social life. Perimenopausal women's health and quality of life can be maintained and improved through preventive care, life style modification, early diagnosis of risk factor and appropriate treatment.
\end{abstract}

Keywords: Menorrhagia, Abnormal uterine bleeding, Perimenopausal women, Endometrium

\section{INTRODUCTION}

Abnormal uterine bleeding (AUB) is one of the most common health problems come across by women of perimenpausal age group. Stages of reproductive aging workshop (STRAW) defined perimenopause as the commencement with menopausal transition and ending 12 months after the last menstrual period. It is associated with menstrual and endocrinal alteration and may last for many years (2 to 8 years). ${ }^{1}$ AUB accounts for two thirds of all hysterectomies worldwide, thereby a great reason of morbidity and mortality in this age group. ${ }^{2}$ It accounts for about $5-10 \%$ of cases in the outpatient clinic setting. About $20 \%$ of affected individuals are in the adolescent age group, and $50 \%$ of affected individuals are aged $40-$ 50 years. ${ }^{3}$ If the treatment is not initiated early, it can lead to severe anemia. If blood loss is acute, it can result in hypovolemic shock and the patient may collapse if the bleeding is too severe. The most common etiology of AUB is dysfunctional uterine bleeding (DUB) which has no any noticeable organic cause. It is usually due to hormonal disturbances: reduced level of progesterone causes low levels of prostaglandin F2alpha and cause menorrhagia (abnormally heavy flow); increased levels of 
tissue plasminogen activator (a fibrinolytic enzyme) lead to more fibrinolysis. Organic causes of AUB includes benign pelvic lesion (fibroid, adenomyosis, cervical and endometrial polyp, tuberculosis), infection, trauma, iatrogenic (hormonal replacement therapy, contraceptive use, anticoagulant therapy), malignancy of cervix, endometrium or ovary, systemic illness (hypertension, diabetes mellitus, thyroid disorders), etc. AUB can be classified as ovulatory or an ovulatory, depending on whether ovulation is occurring or not. ${ }^{4}$ The investigation of a patient with AUB in perimenopausal age begins only after thorough history, general physical examination and systemic evaluation. Once malignancy and significant pelvic pathology have been ruled out, medical treatment is an effective first line therapeutic option for abnormal uterine bleeding. Effective medical treatment options include Non-hormonal (non-steroidal anti-inflammatory drugs, antifibrinolytics) and hormonal (combined hormonal contraceptives, levonorgestrel-releasing intrauterine system, Oral progestins (long phase, days 5 to 26), Depot- medroxyprogesterone acetate, Danazol, GnRH-agonists). ${ }^{5}$ The rationale behind the study was to determine incidence of AUB in women of perimenopausal age group.

\section{METHODS}

Study area: OPD \& Gynae emergency, in the Dept. of Obstetrics and Gynaecology.

It was Retrospective observational study.

\section{Study population}

The 200 cases of abnormal uterine bleeding between 40 55 years of age attending OPD \& Gynae emergency.

Study duration was from January 2018 to January 2019.

\section{Sampling technique}

Simple random sampling.

\section{Inclusion and exclusion criteria}

All perimenopausal (40 to 55 year) women presenting with abnormal uterine bleeding were included and women with active or recent pelvic inflammatory disease, patient in menstruation phase, pregnancy or suspected pregnancy complications and cervical lesions were excluded from the study.

\section{Methodology}

Data relating to history, clinical examination and relevant laboratory results required for the study were retrieved from hospital records. All the data were duly recorded in the standard prepared proforma. Details of each patients were recorded and analysed with respect to aetiopathology, age, parity, marital status, socioeconomic status, treatment options and other medical disorders.

\section{Statistical analysis}

Data was consolidated and entered into Microsoft Excel spreadsheet and then transferred to Epi info version (7.1.3.0. centre for disease control and prevention, Atlanta, Georgia, USA, 2013) software for analysis.

\section{RESULTS}

As per Table 1 sixty-six percent of the cases belonged to age group of $40-45$ years followed by $25 \%$ in $46-50$ years. Around $9 \%$ of cases were above 51 years.

Table 1: Distribution of cases according to age.

\begin{tabular}{|ll|}
\hline Age (years) & Cases of AUB (\%) \\
\hline $40-45$ & $132(66)$ \\
\hline $46-50$ & $50(25)$ \\
\hline$>51$ & $18(9)$ \\
\hline
\end{tabular}

Table 2: Causes of AUB.

\begin{tabular}{|ll|}
\hline Causes & N $(\%)$ \\
\hline DUB & $120(60)$ \\
\hline Fibroid & $42(21)$ \\
\hline Adenomyosis & $10(5)$ \\
\hline PID & $8(4)$ \\
\hline Endometriosis & $6(3)$ \\
\hline Endometrial carcinoma & $5(2.5)$ \\
\hline Cervical cancer & $5(2.5)$ \\
\hline Cervical polyp & $2(1)$ \\
\hline Hypothyroidism & $2(1)$ \\
\hline
\end{tabular}

In Table 2 the most common cause of AUB is dysfunctional uterine bleeding (DUB) seen in $60 \%$ of patients followed by the most organic cause was fibroid in $21 \%$, other causes include adenomyosis (5\%), Pelvic inflammatory disease (4\%), endometriosis (3), endometrial carcinoma, cervical cancer (2.5). $1 \%$ patient also showed hypothyroidism as the cause of AUB.

Table 3: Pattern of menstrual irregularities in AUB cases.

\begin{tabular}{|ll|}
\hline Pattern & N $(\%)$ \\
\hline Menorrhagia & $140(75)$ \\
\hline Metrorrhagia & $35(18)$ \\
\hline Polymenorrhoea & $10(3)$ \\
\hline Polymenorrhagia & $10(3)$ \\
\hline Post-menopausal bleeding & $5(1)$ \\
\hline
\end{tabular}

Menorrhagia is the most common menstrual irregularity pattern seen in $75 \%$ of women, followed by metrorrhagia in $18 \%$. $3 \%$ of women had polymenorrhoea and polymenorrhagia. 
Table 4: Parity wise case distribution.

\begin{tabular}{|ll|}
\hline Parity & N $(\%)$ \\
\hline 0 & $10(5)$ \\
\hline $1-3$ & $165(80)$ \\
\hline$>3$ & $25(15)$ \\
\hline
\end{tabular}

It is evident from our study that AUB was muchmore common in multiparus women than in nulliparus.

Out of 200 cases, 190 (95\%) belonged to para 1and above, and among these, AUB was more common in para $1-3(80 \%)$.

Table 5: Treatment plan in AUB cases.

\begin{tabular}{|ll|}
\hline Treatment & N $(\%)$ \\
\hline Hysterectomy & $135(67.5)$ \\
\hline Polypectomy & $6(3)$ \\
\hline D \& C & $7(3.5)$ \\
\hline Referred to oncology & $10(5 \%)$ \\
\hline Drugs & $40(20 \%)$ \\
\hline
\end{tabular}

Table 5 suggest majority of cases $(n=150,75 \%)$ in our study treated surgically out of which 135 cases undergone hysterectomy. 6 patients undergone polypectomy and diagnostic curettage, and 7 patient undergone dilatation\& curettage. $40(20 \%)$ patients were treated with drugs depending on the cause of AUB and only 3 patients managed with reassurance, symptomatic relief and haematinics. $10(5 \%)$ cases of endometrial and cervica cancers were referred to Oncology Department.

\section{DISCUSSION}

A regular menstruation has always been acknowledged as an indication of good reproductive health. A change in the amount, duration or regularity of this periodic loss is therefore regarded as somewhat going wrong and not recognized by any women especially in the perimenopausal age. In the present study out of 200 women sixty-six percent of the cases belonged to age group of 40-45 years followed by $25 \%$ in $46-50$ years. Around $9 \%$ of cases were above 51 years. AUB was much more common in multiparus women than in nulliparus. Out of 200 cases, 190 (95\%) belonged to para 1 and above, and among these, AUB was more common inpara 1-3 (80\%). Menorrhagia is the most common menstrual irregularity pattern seen in $75 \%$ of women, followed by metrorrhagia in $18 \%$. $3 \%$ of women had polymenorrhoea and polymenorrhagia. majority of cases $(n=150,75 \%)$ in our study treated surgically out of which 135 cases undergone hysterectomy. 6 patients undergone polypectomy \&diagnostic curettage, and 7 patient undergone dilatation\& curettage. Katke et al showed that $43.9 \%$ patients were having fibroid as related pathology on ultrasound. ${ }^{6}$ Kumari in a series of 180 patients detected organic pathology in $37 \%$ of the cases and $63 \%$ patients were having without any organic pathology ${ }^{7}$.
Their study was mainly on cases of DUB but our study is based on all cases of AUB. So, in our study incidence of organic causes is more. Janet and Swami also found that majority of perimenopausal cases with AUB had no organicpathology. ${ }^{8,9}$ This is probably due to modification in Hypothalamic-Pituitary-Ovarian function preceding menopause. Kotagasti et al study found menorrhagia $(33 \%)$ as the commonest bleeding pattern in AUB, followed by oligomenorrhoea (19.97\%) and polymenorrhoea (18.35\%). ${ }^{10}$ Reich et al showed that hysterectomy is the definitive treatment for DUB and has a higher rate of patient satisfaction. ${ }^{11}$

\section{CONCLUSION}

Perimenopause is an important age group where AUB is common. Many therapeutic approaches to the management of perimenopausal disturbances exist. The perimenopausal women quality of life and health can be maintained \& improved through preventive care, lifestyle modification, early diagnosis of disease and intervention when appropriate. Our clinical aim should be to enhance the women health during and after perimenopause.

\section{Funding: No funding sources}

Conflict of interest: None declared

Ethical approval: The study was approved by the Institutional Ethics Committee and Research Committee of College

\section{REFERENCES}

1. Soules MR, Sherman S, Parrott E. Stages of reproductive aging (STRAW). J Womens Health Gender Based Med. 2001;10(9):843-8.

2. Kotdawala P, Kotdawala S, Nagar N. Evaluation of endometrium in peri-menopausal abnormal uterine bleeding. J Midlife Health. 2013;4(1):16-21.

3. Rezk M, Masood A, Dawood R. Perimenopausal bleeding: Patterns, pathology, response to progestins and clinical outcome. J Obstet Gynaecol. 2015;35(5):517-21.

4. Padubidri VG, Daftray SN. Shaw's textbook ofGynaecology/ 16 th edition/chapter 24/page335348.

5. Janet R. Albers, Sharon K. Hull, and Robert M. Wesley: Abnormal Uterine Bleeding. Am Fam Physician. 2004;69(8):1915-26.

6. Katke RD, Zarariya AN. Use of diagnostic hysteroscopyin abnormal uterine bleeding in perimenopausal age group and its clinicopathological co-relation with ultrasound and histopathology findings: experience in atertiary care institute. Int $\mathbf{J}$ Reprod Contracept Obstet Gynecol. 2015;4:413-8.

7. Kumari A, Kumar R. Abnormal uterine bleeding in peri-menopausalage: An observational study. Indian J Obstet Gynecol Res. 2018;5(4):539-43.

8. Janet R. Albers, Sharon K. Hull, and Robert M. Wesley: Abnormal Uterine Bleeding. Am Fam Physician. 2004;69(8):1915-26. 
9. Swami MB. Histopathological evaluation ofendometrium in pre and postmenopausal uterine bleeding. Indian J Obstetr Gynaecol Res. 2015;2(4):264-9.

10. Kotagasti. Prevalence of different menstrual irregularitiesin women with abnormal uterine bleeding (aub) - anobservational study. Int J Cur Res Rev. 2015;7(10):66-70.
11. Reich H. Hysterectomy as treatment for dysfunctional uterine bleeding. Baillieres Best Pract Res Clin Obstet Gynaecol. 1999;13(2):251-69.

Cite this article as: Chennuru R, Potnuru R. Abnormal uterine bleeding in women of perimenopausal age: a retrospective study. Int J Reprod Contracept Obstet Gynecol 2019;8:2406-9. 